\title{
Rebuilding Mathematically: A Study of the Rebuilding of Lisbon and London
}

\author{
Maria Zack ${ }^{1}$
}

Published online: 23 April 2015

(C) Kim Williams Books, Turin 2015

\begin{abstract}
In 1666, the City of London burned to the ground in what has become known as the "Great Fire of London". In 1755, just 89 years later, Lisbon was destroyed by an earthquake. Throughout this time period Lisbon and London were joined by extensive commercial ties and there are several interesting parallels between the rebuilding of these two great cities. Both processes were led by individuals deeply committed to modernization and the use of the scientific method as a part of reconstruction. At the time of the 1666 London fire, calculus was being discovered in Europe and there were early attempts to create mathematical models for the properties of materials. By 1755, the elasticity of beams was reasonably well understood and some of the first seismically engineered structures were built in Lisbon. This paper examines some of the similarities and differences between how London and Lisbon were reconstructed and the role that mathematics and engineering played in their reconstruction.
\end{abstract}

\section{Introduction}

At different times, Portugal and England have been great Naval powers whose mastery of the practical mathematics of boat building, navigation, and military construction allowed each nation to assemble wide-ranging empires. Over many centuries there have been linkages between these two nations, and in the seventeenth century, a series of treaties $(1642,1654)$ and the marriage of Catherine of Braganza of Portugal to Charles II of England in 1662 further solidified the relationship (Lodge 1933, pp. 212-217). The Methuen Treaty of 1704 clearly

Maria Zack

mzack@pointloma.edu

1 Mathematical, Information and Computer Sciences, Point Loma Nazarene University, 3900 Lomaland Drive, San Diego, CA 92106, USA 
indicated the preferential nature of their affiliation. In the treaty the Portuguese king agrees that "there shall be admitted at all times into Portugal, woollen Cloths, and other the Woollen Manufactures of England" and the English queen agrees "at all times ... to admit into England, Wines gathered from the Vineyards belonging to the Portugal Dominions" (Francis 1960, p. 121).

From 1650 to 1760 , the trade in textiles and port fostered a significant amount of human interaction. Lisbon was host to a large expatriate English community and in that same period London was home to many Portuguese diplomats and intellectuals. In this same 100 year span, both London and Lisbon saw catastrophic destruction, followed by substantial, innovative and creative rebuilding.

\section{Two Great Disasters}

What has become known as the Great Fire of London began in the early morning hours of Sunday September 2, 1666, in a bakery on Pudding Lane. What started as a small fire was fed by strong winds and soon raged out of control. The famous diarist Samuel Pepys wrote in his diary on September 2, 1666:

By and by Jane [a maid] comes and tells me that she hears that above 300 houses have been burned down tonight by the fire we saw, and that it is now burning down all Fish Street, by London Bridge. So I made myself ready presently and walked to the Tower; and there got up upon one of the high places, ... and there I did see the houses at the end of the bridge all on fire, and an infinite great fire on this and the other side the end of the bridge... (Pepys 1999, pp. 155-156).

The fire burned for 4 days before being extinguished. By the time the fire was over, $85 \%$ of the City of London (the area within the walls) was destroyed, 50,000 people were left homeless, and most churches, businesses and government buildings were beyond repair (Bennett et al. 2003, pp. 28-29).

Eighty-nine years later, on the morning of November 1, 1755, disaster struck Lisbon in the form of an earthquake. Seismologists today estimate that the earthquake was between 8 and 9 on the Richter scale. One account of the events reads:

It was the morning of All Saints' Day, and the devout population of Lisbon were hurrying to attend divine worship in the numerous churches, which on that day, according to custom, were brilliantly illuminated in honor to the festival, when, at four minutes after nine, the first convulsive shocks were perceived; and soon after, this proud city became a heap of undistinguishable ruins (Smith 1845, pp. 484-485).

As the result of the earthquake the city began to burn. After several days, the fire in Lisbon was extinguished. This calamity left thousands homeless and destroyed many of the churches and commercial, government and royal buildings. The Baxia, which was Lisbon's commercial center and contained the port near the river Taugus, had been built on alluvial soils and fine sand. Once the earthquake began, this 
neighborhood of narrow streets and tall buildings collapsed in on itself (Mullin 1992, p. 2).

\section{The Planners and Designers}

The kings of both England and Portugal needed to identify strong teams that were capable of rebuilding their nations' main commercial centers. However, King Charles II of England and King José I of Portugal took very different approaches to creating and empowering their design teams.

Shortly after London's 1666 fire, King Charles II appointed two interconnected teams to rebuild the city. The king appointed Roger Pratt, Hugh May and Christopher Wren as his Commissioners for Rebuilding. The City of London appointed Peter Mills, Edward Jerman and Robert Hooke as the Surveyors for the rebuilding effort. Though Wren and Hooke were both junior members on their respective teams, they soon took a leading role in the rebuilding of London (Bennett et al. 2003, pp. 31-32).

Wren and Hooke began their life-long pattern of collaboration during their student days at Oxford in the 1650s, and they were two of the founding members of the Royal Society. For much of the four decades after the Great Fire, the massive effort to rebuild London was led by these two friends and scientific collaborators. Wren's ability to move comfortably among the aristocracy and Hooke's many relationships with tradesmen proved useful in carrying out complex projects (Zack 2008, pp. 117-126). These skills turned out to be essential, because the London reconstruction team had been given limited authority and thus almost all projects involved design compromises, and negotiations with multiple individuals from London's ecclesiastical, political, and royal hierarchies.

In contrast, the recovery of Lisbon after the earthquake of 1755 was overseen by a single individual, Sebastião José de Carvalho e Melo, the Marquis of Pombal. It is from this title that the term "Pombaline architecture" is derived. Much has been written about Pombal, and little of it is complimentary. What is clear is that he had a gift for organization as well as a talent for achieving his desired outcome. Shortly after the earthquake Pombal took control of the city and organized the early recovery efforts (burying bodies, feeding the homeless, etc.) (Kendrick 1955, pp. 73-82). Some have called the rebuilding of Lisbon an exercise in "despotic planning” (Mullin 1992, pp. 1-2).

King José I of Portugal, in collaboration with Pombal, appointed a reconstruction team that consisted of the Royal Engineer and Director of the Military Academy of Fortification, General Manuel de Maia; Senate Architect, Captain Eugenio dos Santos; and Architect to the Royal Palaces and Military Orders, Lieutenant Colonel Carlos Mardel. All three of these men were military engineers with extensive experience in military architecture (Mascarenhas 1996, pp. 62-63). It was Manuel da Maia's vision that was the driving force behind the reconstruction of Lisbon and the "austerity and rationality" of the Pombaline style is attributed to da Maia (Mascarenhas 1996, p. 25). 
This team represented three generations of Portuguese design history. Manuel da Maia, who was in his 80 s when the rebuilding began, had been trained in military fortification, architecture and engineering. Before the earthquake da Maia had designed a new plan for Lisbon and thoroughly understood the city's problems. Carlos Mardel, who was in his 60s at the start of the rebuilding, was well grounded in the Baroque style and was very comfortable moving in royal circles. Eugenio dos Santos was a student of da Maia and was in his 40s when construction began. Dos Santos was pragmatic and fully understood the need for speed in the reconstruction of Lisbon; it is said that he best understood Pombal's "vision" for how reconstruction in Lisbon should reflect a new society (Mullin 1992, p. 5-6).

\section{Designing a New City}

The London of early 1666 (Fig. 1) and the Lisbon of 1755 (Fig. 2) shared many common features. Both were port cities that contained narrow medieval streets which were clogged with both commerce and sewage; and disease and fire spread rapidly in these urban centers. For both London and Lisbon, a city in ruins provided the opportunity to build a new kind of urban center. The designers of both cities were steeped in the scientific and rational ideas of the Enlightenment and sought to "rationalize" the plans for their communities.

In London a number of new plans for the city were generated rapidly. On September 19, 1666, just 2 weeks after the fire was extinguished, Robert Hooke presented his plan for the new London at a meeting of the Royal Society. Though no copy of Hooke's map is known to have survived, it was reported to have consisted of rectilinear grids (Cooper 2003, p. 112). Christopher Wren also drafted a new plan for the city. It had rectilinear elements but also included some grand boulevards (see Fig. 3).

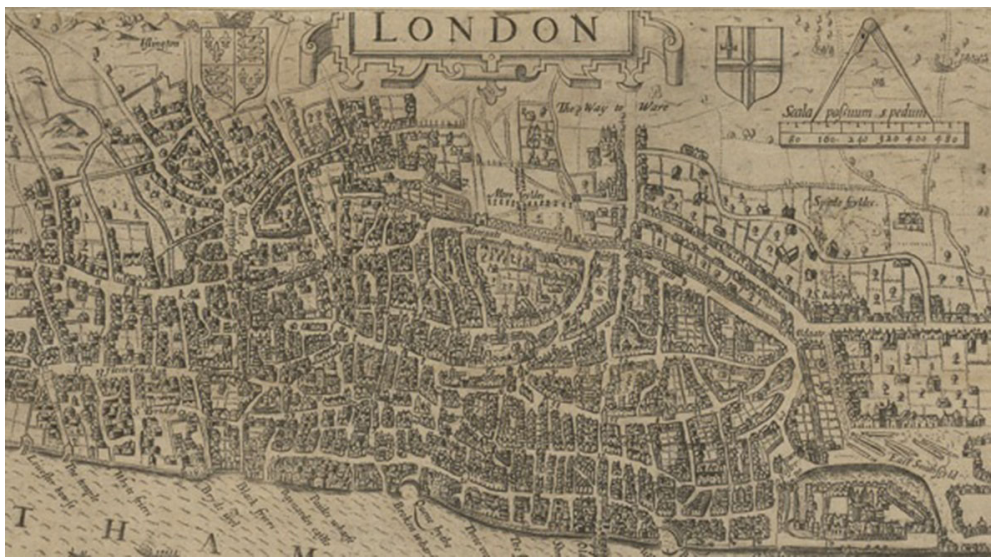

Fig. 1 John Nordon's Map of Pre-Fire London (c1593, engraved 1653). Reproduced with permission of the British Library (C) The British Library Board (Maps Crace Port. 1.33) 


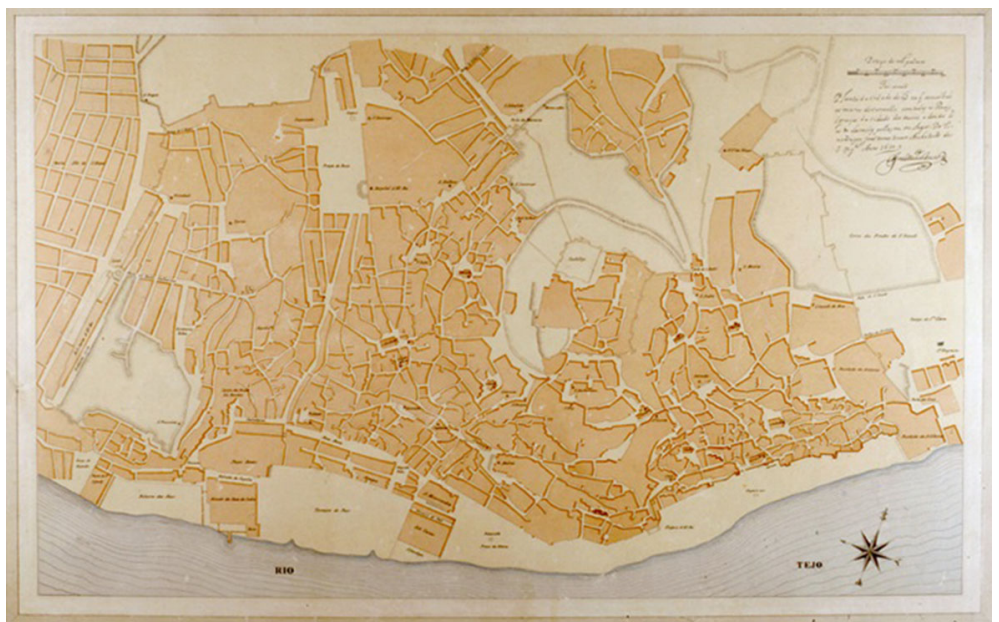

Fig. 2 Pre-Earthquake Lisbon (c1650). Collection of the City Museum of Lisbon. Reprinted by Permission

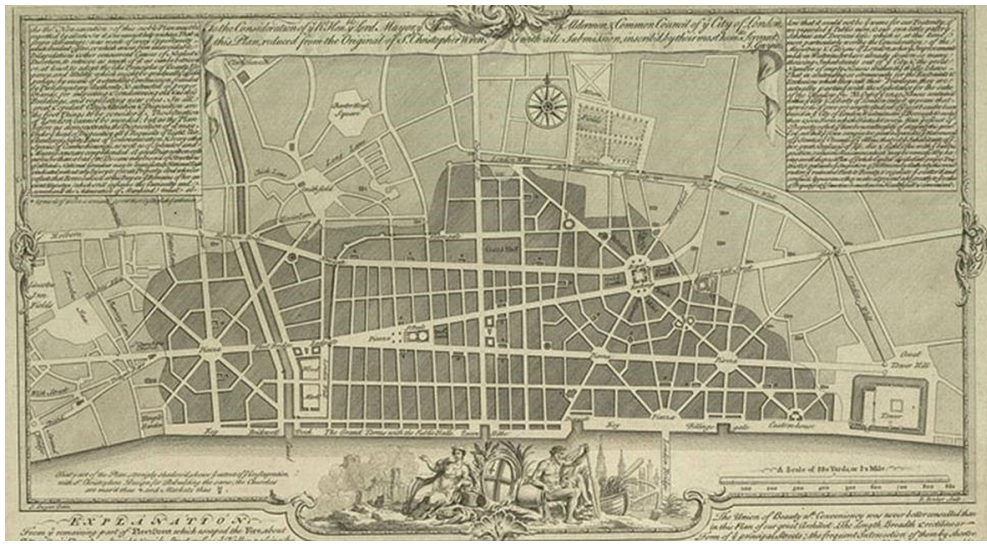

Fig. 3 Wren's Proposed Map of London. Reproduced with Permission of the British Library. (C) The British Library Board (Maps Crace Port. 17.6)

The Members of the English Parliament engaged in some debate about the best manner for rebuilding the city. In a letter to Robert Boyle (October 2, 1666), Henry Oldenberg, the Secretary of the Royal Society, says:

The rebuilding of the city, as to the model, is still very perplex, there appearing three parties in the house of commons about it. Some are for a quite new model, according to Dr. Wren's draught; some for the old, yet to build with bricks; others for a middle way, by building a key, and enlarging some streets, but keeping the old foundations and vaults (Cooper 2003, p. 115). 
London was not rebuilt in a new configuration; instead a compromise plan was adopted. The Rebuilding Act of 1667 authorized the rebuilding of a city more uniform than its predecessors, better suited to trade and hygiene and less susceptible to fires. The Act limited structures to four stories and required most construction to be done with brick and stone (Cooper 2003, pp. 125-132). The "new" plan for London (see Fig. 4) did achieve several aims: building regulations that would reduce the destruction caused by fire, rudimentary systems for dealing with sewage, and wider streets to provide for better flow of traffic and air. However, it was neither the elegant plan proposed by Wren nor the orderly, rectilinear plan proposed by Hooke.

As with London, the redesign of Lisbon began very soon after the city was destroyed. With the approval of King José I, the Marquis de Pombal moved quickly to sort through four options for rebuilding Lisbon: rebuilding Lisbon as it had been, rebuilding the city with minor changes including the widening of some streets, rebuilding Lisbon to a completely new plan or rebuilding Lisbon in a different geographical location. Pombal made the decision to use the third option and rebuild Lisbon in place with a new plan (Mullin 1992, p. 1).

Da Maia insisted that the new city plan improve sanitation, provide greater safety in earthquakes, reduce the spread of fire and allow people and carriages to move more freely on the streets. Da Maia is said to have drawn inspiration from the rebuilding of London after the fire of 1666, and hints of that inspiration can be seen in the final plans. Clearly Wren and Hooke had addressed many of the same urban problems facing da Maia, but they had to work within the framework of a "compromise" rebuilding plan. So da Maia and his team were given additional design opportunities that were not afforded Wren and Hooke (Mullin 1992, pp. 6-7).

The Portuguese team drew up six different plans for the city and they were thoroughly reviewed. All of the plans reflected the general principles of da Maia: the

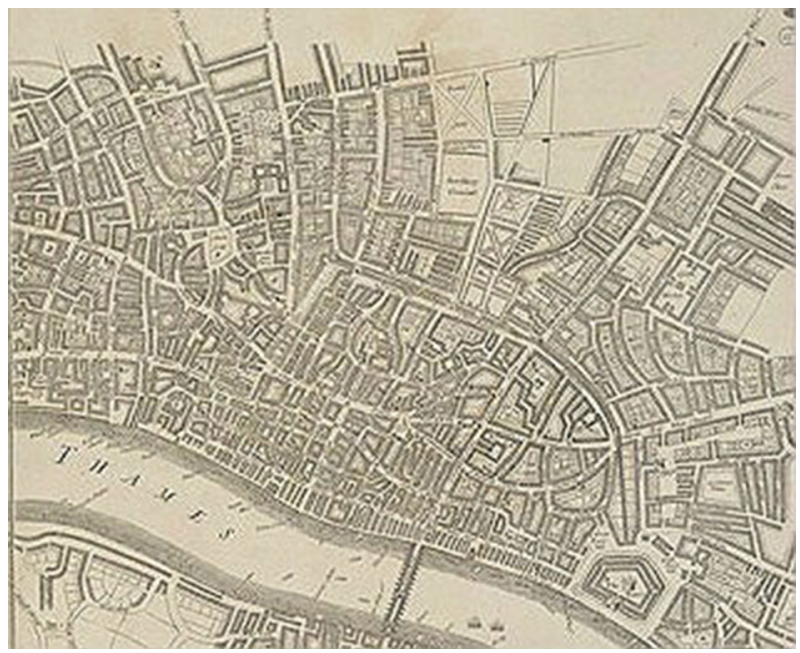

Fig. 4 A New Map of the City of London (c1720). Reproduced with Permission of the British Library. (C) The British Library Board (Maps Crace II, 82) 


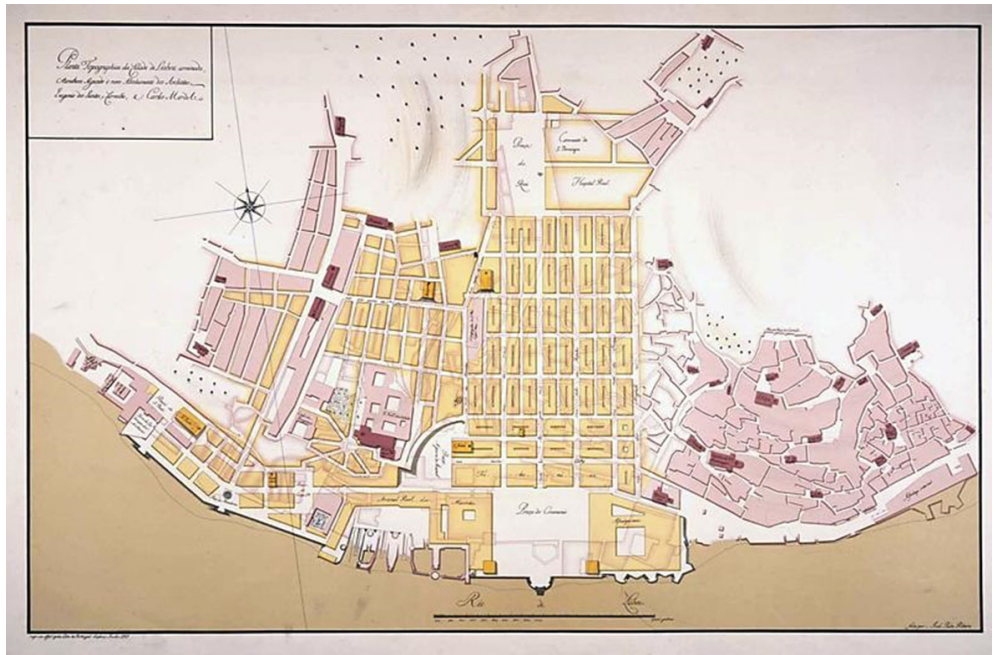

Fig. 5 Dos Santos and Mardel's plan for Lisbon. Collection of the City Museum of Lisbon. Reprinted by Permission

streets were rectilinear, the buildings were of limited height and the main squares in the city were connected in a rational way. The plan that was selected was drawn by dos Santos and Mardel (see Fig. 5) (Mascarenhas 1996, pp. 39-45).

Lisbon was rebuilt according to this plan and this same design is still visible in the twenty-first century Baxia Pombalina neighbourhood.

\section{Building New Structures}

The first half of the seventeenth century produced a significant number of transformational publications in mechanics. These include Galileo Galilei's Dialogo (1632) and Discoursi (1638), Rene Descartes' Principia philosopiae (1644), Evangelista Torricelli's Opera geometrica (1644) and Pierre Gassendi's Syntagmaphilosophicum (from the 1640s; published 1658). These works were the beginning of the intellectual revolution that sought to understand the physical world mathematically.

Marin Mersenne, who was a prolific correspondent, was the hub of much of this scientific community and when he died in 1648, this community of scholars lost its nodal point for exchange. However, in the late 1650s and 1660s this role was taken up by the newly founded scientific societies: the Royal Society (founded in 1660) and the French Académie (founded in 1666). The seventeenth century also witnessed the emergence of the scientific journal, which provided a venue for recording experiments and publishing brief theoretical reports. These include the influential Philosophical Transactions of the Royal Society, the Memoires of the French Academie, the Journal des sçavans (published in Paris and Amsterdam) and the Acta eruditorum (published in Leipzig) (Meli 2006, pp. 162-164). 
Thus the rebuilding of London and Lisbon was done in the context of an emerging understanding of mechanics. The connection between science and construction can be seen in some interesting ways in the reconstruction of these two cities.

\section{Mathematical Context for St. Paul's}

In the seventeenth century, what we would call modern engineering was in its infancy. At that time architects and builders sought to move from "rules of thumb" and passed down traditions to the ability to mathematically analyze the structural attributes of a building and the interactions of different structural components (Wells 2010, pp. 89-93). Hooke and Wren were steeped in the scientific literature of the day and we can see some evidence of the use of the mathematics of materials in the design of the dome of St. Paul's Cathedral.

DaVinci's fifteenth century Codex Arundel (1480s) provided some early commentary on the structural nature of domes, and Michelangelo, Giacomo della Porta and Domenico Fontana advanced the technology of dome construction by making use of a double dome in the building of St. Peter's in Rome (1560s to 1590s). However, it was Galileo's Discorsi e dimostrazioni matematiche, intorno à due nuоuescienze (Discourses and Mathematical Demonstrations Relating to Two New Sciences) (1638), where the breaking and bending of materials is carefully discussed. The drawing shown in Fig. 6 is perhaps one of the most widely recognized of Galileo's illustrations.

Looking at Fig. 6 it is clear that with sufficient load, the beam will break at point B where it is embedded in the wall. In day one of Discorsi, Galileo discusses the

Fig. 6 Galileo's Loaded Cantilever in Discorsi. Reproduced by permission of The Huntington Library, San Marino, California

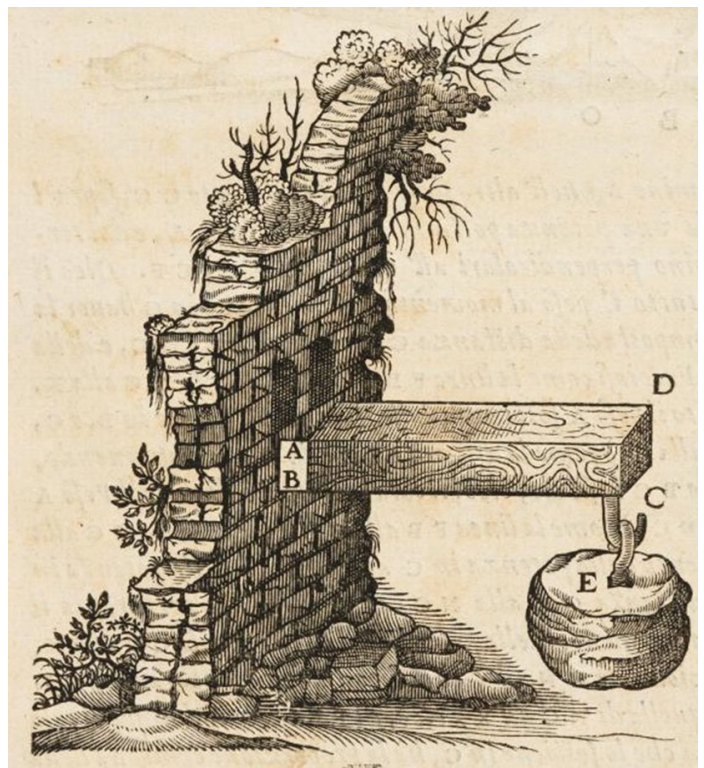


"absolute strength" of materials (tensile strength). In day two he builds a relationship between the absolute strength of the material and the moment of the applied weight around a specific point (B in Fig. 6). The basis of his formula is the recognition that at the instant when a break occurs, the moment of the applied weight and the moment of the absolute strength must be in equilibrium. Galileo's conclusion can be represented in modern notation with the equation: WL $=(1 /$ 2)SX. In this equation $\mathrm{W}$ is the weight applied at $\mathrm{E}$ in Fig. 6, $\mathrm{L}$ is the distance from the point where the beam intersects the wall (AB) to the face (DC) in Fig. 6, S is the absolute strength (a property of the specific material) and $\mathrm{X}$ is a measure of the size of the cross section of the beam (the square end of the beam near DC in Fig. 6) (Meli 2006, pp. 91-94). By the 1670s the problem of resistance and bend in materials, with a particular focus on wooden beams, was discussed in both the Royal Society and the Paris Académie (Meli 2006, pp. 248-253).

In a late 1670/71 meeting of the Royal Society, Hooke and Wren presented some thoughts about the strength of different types of arches including "the line of an arch supporting a weight assigned". At another meeting of the Royal Society late in 1671 Hooke presented further information about weight-sustaining domes in the shape of a "cubico-parabolical conoid", a dome that uses the cubic on the positive numbers and rotates it about the vertical axis (Heyman 1998, pp. 39-42). By 1675 Hooke understood that the most structurally sound arch was a catenary. "As hangs the flexible line, so but inverted will stand the rigid arch" (Gerbino and Johnston 2009, p. 164).

On June 5, 1675, Hooke writes in his diary "At Sir Chr. Wren...He [Wren] was making up my principle about arches and altered his module [model] by it" (Hooke 1935 , p. 163). The timing of this diary entry is significant. The design for the postfire St. Paul's involved a great deal of political wrangling between Wren and the clergy of St. Paul's because the church that Wren wanted to build was not the church that the clergy desired. In the spring of 1675 a compromise was reached, and in May of 1675 this compromise design (known as the Warrant design) was approved for construction by King Charles II. However, the King told Wren privately that he could make "variations, rather ornamental, than essential, as from Time to Time he should see proper", thus leaving management of the construction to Wren. By the summer of 1675 , Wren had begun digging a foundation for a building that more closely resembled the church he had envisioned (Jardine 2002, pp. 293-294). So it appears that Hooke and Wren were talking about catenary arches at the precise time that Wren was working on the final (and actual) design of St. Paul's.

Wren had probably seen double domes during his 1665-66 visit to Paris. Wren was also aware of Leonardo da Vinci's analysis of the cracks in domes presented in Codex Arundel, and that the cracks in the dome of St. Peters in Rome had come from what today we would call hoop stress (Falter 1998, pp. 56-57). Wren's clever triple dome design with the central cone carrying the weight of the lantern for St. Paul's (Fig. 7) was an elegant solution to the problems that had been seen in St. Peter's. But despite the fact that Wren and Hooke were involved in discussions about mechanics and the properties of materials at the time of the design of St. Paul's, there is very little documentary evidence that the structural design of the 
Fig. 7 The Triple Dome.

Drawing by Lisa Gilbertson.

Reproduced by permission
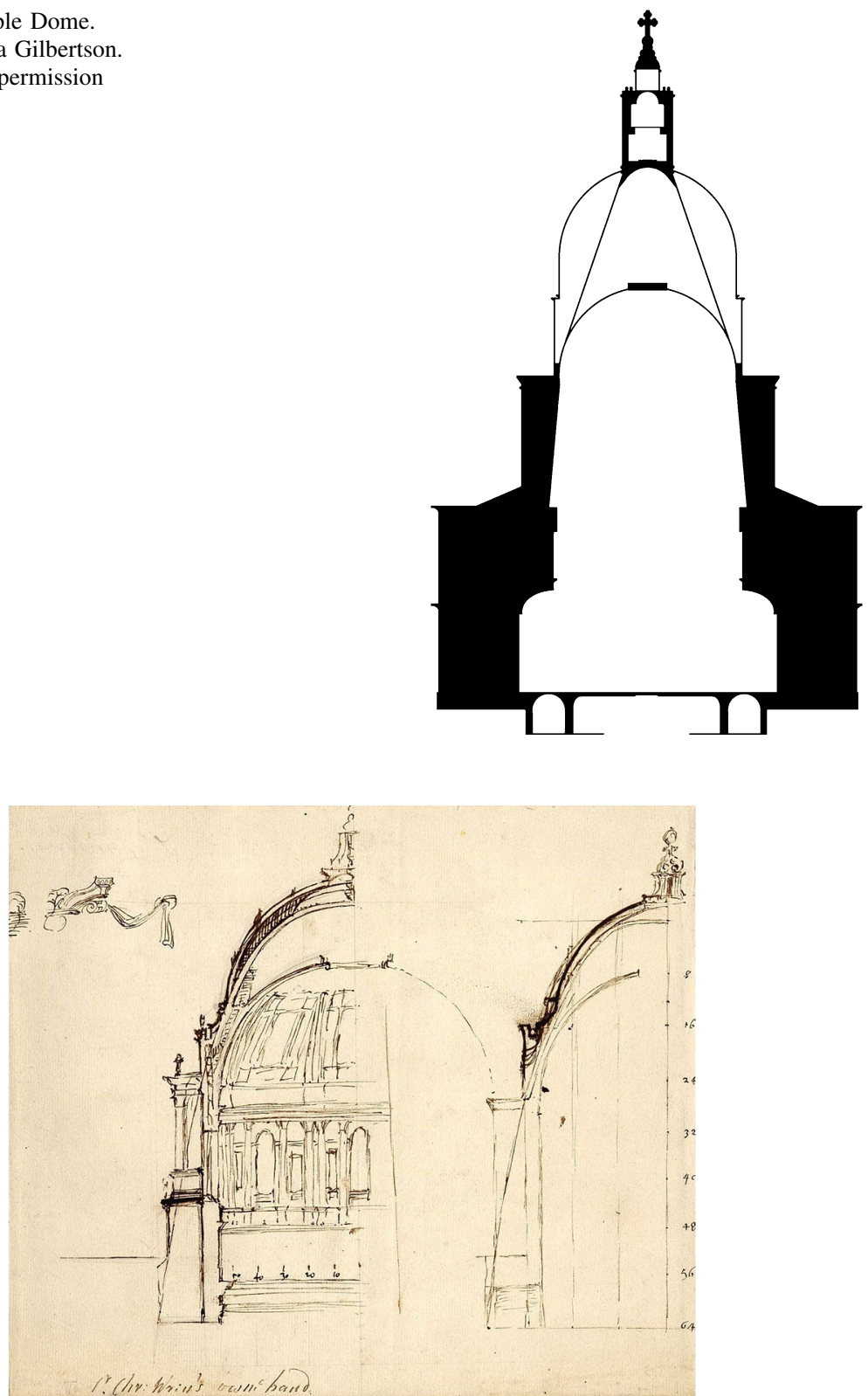

Fig. 8 Wren's sketches for the design of the St. Paul's dome (circa 1690). This drawing reproduced courtesy of the British Museum, London. (C) Trustees of the British Museum

dome was based on more than the building traditions handed down by generations of craftsmen. However, the British Library is home to a small drawing from approximately 1690 for the triple-dome of St. Paul's (see Fig. 8). 
This drawing is in Wren's own hand and the numerical grids show that Wren was using the cubic to form the central dome of the triple. If you look at the right hand drawing you will see vertical markings. The curve intersects these markings at $(1,1)$ and $(2,8)$ and there is a dot at $(3,27)$ where the curve reaches the buttressing. So, certainly in 1690, some mathematical thought about the cubic parabola was occurring in this stage of the development of the design.

The correct equation for the hanging chain was found independently by Christian Huygens, Gottfried Leibniz and Johann Bernoulli, and was published by Leibniz in 1691 in Acta eruditorum. Hooke's library contained the relevant issues of Acta eruditorum so he knew that the correct equation for a catenary was not a cubic parabola but rather what we would call today a hyperbolic cosine (Jardine 1999, p. 333).

Wren modified the design of the dome several times in the period 1696-1702. As the design evolved, the central dome became more conical in shape, which is closer to the catenary than the cubic parabola. This change can be seen in the drawing done by Wren's draughtsman William Dickinson (Fig. 9). By 1697 David Gregory had shown that when an arch is supported, it is because the catenary is included in its "thickness" or abutment (Gregory 1697, pp. 637-652). The design for St. Paul's shown in Fig. 9 contains Gregory's structural idea, however what was built is not mathematically exact (Gerbino and Johnston 2009, pp. 163-169).

Wren and Hooke were the most mathematical English architects of their time and they were actively members of a scientific community that conducted experiments and created mathematical models that today we would connect with modern

Fig. 9 William Dickinson's Sketches for the Dome of St. Paul's (circa 1696-1702). Reproduced by permission of the Dean and Chapter of St Paul's Cathedral and the London Metropolitan Archive

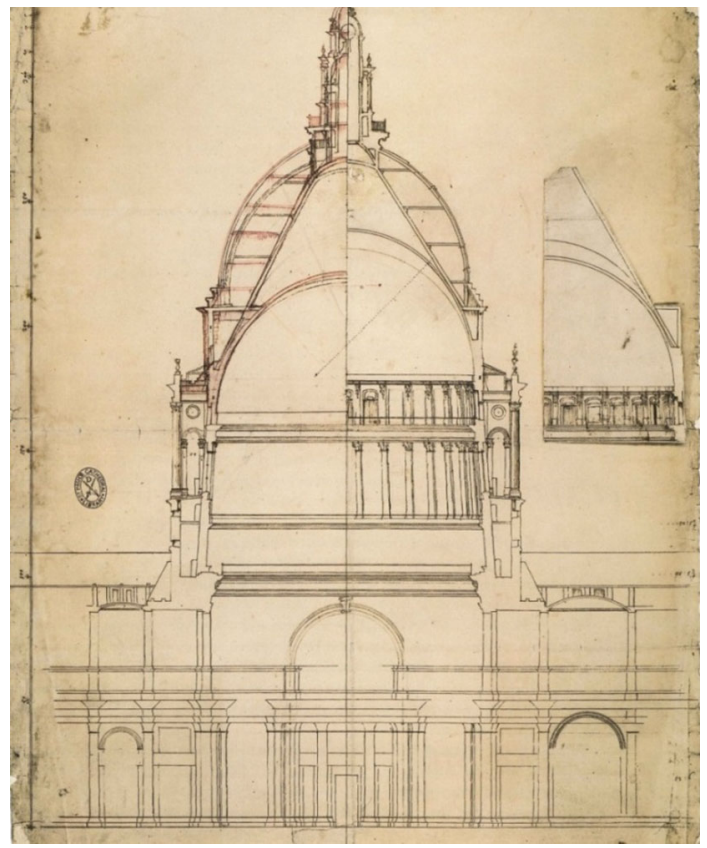


engineering. As late as 1702 they appeared to be incorporating some mathematical ideas into their designs, yet there is limited evidence that the mathematics of materials was being consistently used in construction in eighteenth century London.

\section{Mathematical Context for Pombaline Architecture}

Because Lisbon is in a seismically active region, in 1755 da Maia, dos Santos and Mardel sought to create a plan for rebuilding the Baxia that would provide strong and flexible foundations for the new buildings, decrease the spread of fire between buildings, reduce the risk of building collapses, and decrease injury when buildings collapsed. The new buildings in the Baxia, which came to be known as "Pombaline", were built on composite foundations. The foundation made use of rubble and old foundations as well as timber piles to help stabilize the soil (Cóias e Silva et al. 2001, pp. 944-946). The foundation made use of a system of solid arches supported on timber rafts that were constructed on top of the wooden piles (Mascarenhas 1996, pp. 117-118). This system allowed for movement in the base of the building and can be seen in Fig. 10.

Timber-framed buildings had been in use in Europe before 1755, and it was understood that wood has some amount of elasticity that can adapt to the movement of the soil (Franca 1989, p. 60). The unique contribution of Pombaline architecture is the gaiola (cage) (Dutu et al. 2012, pp. 616-626). The gaiola is a wooden box made up of vertical and horizontal struts braced by diagonal pieces of wood that form "St. Andrew's crosses" (see Fig. 11). This use of diagonals to brace rectangular shapes is an ancient technique for adding stability. The underlying principle is that a triangle is difficult to deform (Mascarenhas 1996, pp. 118-120).

Fig. 10 Foundations with Arches. Taken from

Mascarenhas (1996). Reprinted with permission

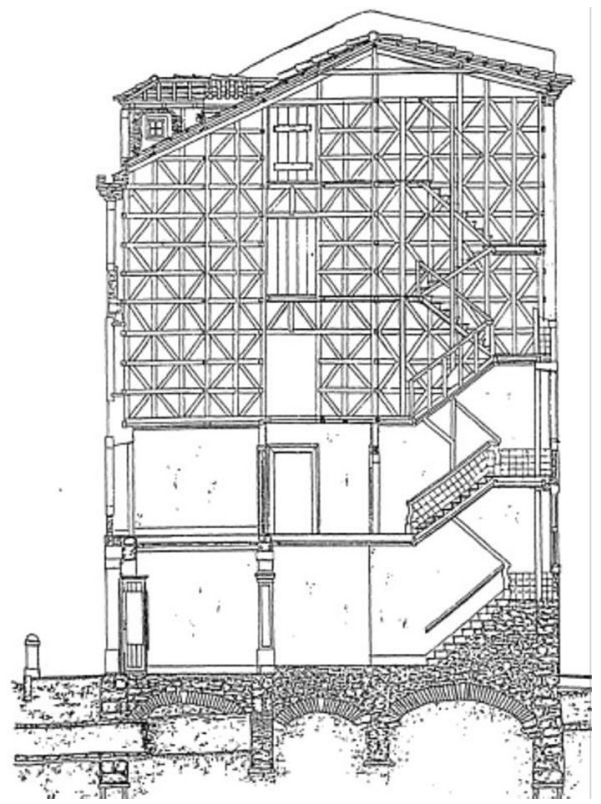



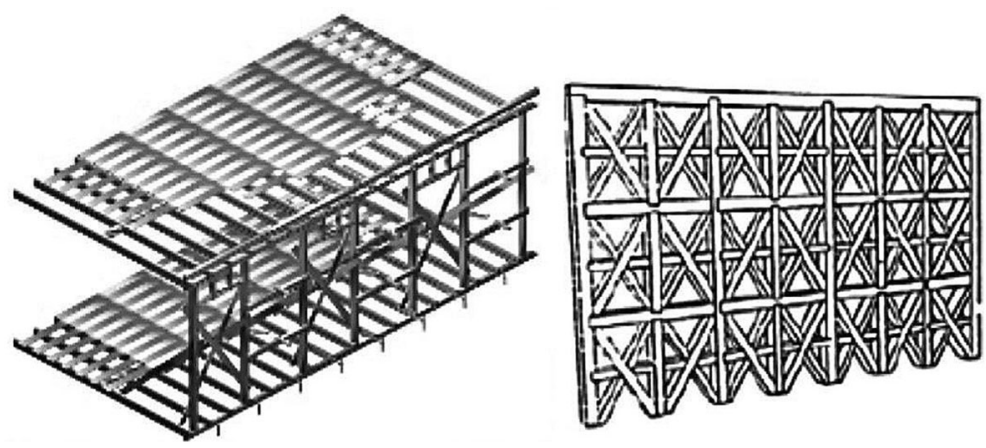

Fig. 11 Gaiola Detail: Cage Shape and St. Andrew's Crosses in Walls. Taken from Dutu (2012). Reprinted with permission

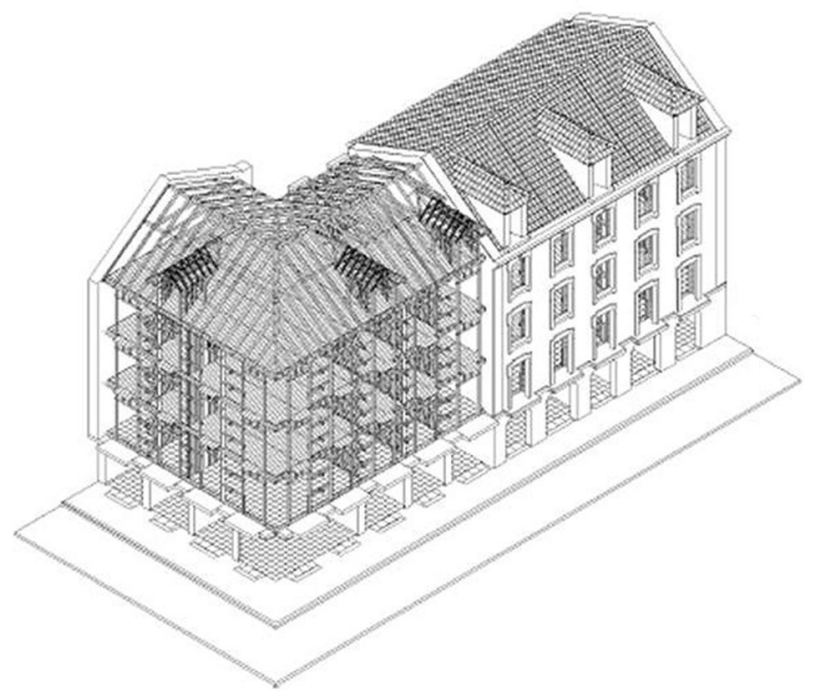

Fig. 12 Gaiola construction showing framework and façade. Image taken from Cóias e Silva (2001). Reprinted with permission

The gaiola design uses a variety of wall types that are combined to provide a seismically stable building. The interior walls of the gaiola are of two types. The first involves a timber framework filled with masonry and rubble that is covered in plaster and the second type is a thin wall made mostly of wood. This construction allowed for flexibility in the interior of the structure, while keeping the walls of low mass. The stone façade of the building was attached to the gaiola (Fig. 12). The fundamental assumption of this design was that in the event of an earthquake the stone exterior would destabilize the building. Thus, the system was designed so that a significant seismic event would detach the stone façade from the gaiola thus allowing the stone to fall to the ground while the elasticity present in the wood would keep the frame of the building intact (Mascarenhas 1996, pp. 118-120). 
By the time the reconstruction of Lisbon began, the European intellectual community had produced some advances in the understanding of mechanics, particularly in the area of the properties of materials. As discussed above, Galileo's original work on the elasticity of beams (Fig. 6) produced an idea that can be represented in modern notation as: $\mathrm{WL}=(1 / 2) \mathrm{SX}$. For the next 100 years a variety of mathematicians worked to improve on Galileo's model. Edme Mariotte conducted a number of experiments and concluded that Galileo's constant of 1/2 was incorrect. Mariotte did identify $1 / 6$ as the correct constant but did not have a mathematical argument to justify his finding (1686). In 1693 Jacques Bernoulli identified that the radius of curvature of a beam is inversely proportional to the bending moment. Pierre Varignon examined the non-linear relationships between stresses and strains (1702) and in the early 1700s Jacques Bernoulli examined the compression and extension that occurs when a beam is bent (1705). In 1729 Bernard Forest de Bélidor published a practical book for engineers in which he reported the outcome of some experiments related to the bending and breaking of beams. By the mid 1740s Daniel Bernoulli and Leonhard Euler developed differential equations to represent the shape of a bent "elastic" beam (Meli 2006, pp. 247-254). So by 1755, the French-speaking intellectual community was developing a sophisticated understanding of the properties of materials.

Unfortunately Portugal's eighteenth century academic community was intellectually isolated from the rest of Europe. With a few exceptions, sophisticated mathematics was not taught in Portuguese universities until after the university mathematics curriculum was reformed in 1772 (Saraiva 1993, pp. 415-421 and Leitao 2003, pp. 230-244). However, da Maia, dos Santos and Mardel, the men responsible for the rebuilding of Lisbon, were not university trained academics, but military engineers and leaders of schools of military engineering. In the mideighteenth century, the texts used to train military engineers in Portugal were Método Lusitânico de desenhar as fortificações das praças regulares e irregulars (Lusitanic Method of Designing the Fortifications of Regular and Irregular Squares) (1680) by Luís Serrão Pimentel and $O$ engenheiro português (The Portuguese Engineer) (1729) by Manuel de Azevedo Fortes. Both of these texts discuss the geometry of fortification, but not the mathematical properties of materials. So while there was significant work being done in Europe on the mathematics of materials, it is not clear how much da Maia, dos Santos and Mardel knew when the gaiola was being developed. Nevertheless there are some intriguing historical facts that point in an interesting direction.

While the formal academic community in Portugal was isolated from Europe, there was an intellectual community that is now referred to as the estrangeirados. Literally translated, this word means foreigners. However the estrangeirados were not foreigners but rather a group of Portuguese clergy, aristocracy, physicians, and military officers that had contact with the European community. This group was important as a network via which ideas from Europe were disseminated in Portugal and they had a role in the reforms at the University of Coimbra in 1772 (Carneiro et al. 2000, pp. 592-594). Much of the estrangeirados' contact with the outside world was with Francophone intellectuals. 
In 1772 when the mathematics curriculum was reformed by the Faculty of Mathematics at the University of Coimbra, many of the first texts used were wellknown French texts translated by the Portuguese mathematician José Monteiro da Rocha. These included books on arithmetic, trigonometry and analysis by Étienne Bézout. Other authors whose work was translated included Charles Bossut (hydrodynamics), Nicholas Louis de Lacaille (optics) and Joseph-Jérôme Lefrançais de Lalande (astronomy) (Figueiredo and Fernandes, 2006, p. 28).

This constellation of facts leads to some interesting questions: Given that Bélidor and Bézout both wrote extensively for a military audience, was some of their knowledge in circulation in the military engineering community in Portugal in the 1750s? Of particular interest is Bélidor's La science des ingénieurs (1729) which specifically discussed the properties of beams. Could the estrangeirados have facilitated the dissemination of key information about the mathematics of materials among the community of military engineers well in advance of the university reforms that came to Coimbra in 1772? We know that Mardel came to Portugal from somewhere else (the speculations include Hungary, Germany, France and Holland). Did Mardel bring with him specific knowledge about the properties of timber frames?

It is interesting to note that in the 89 years between the London fire in 1666 and the Lisbon earthquake in 1755, the mathematical understanding of physical systems and the properties of materials made significant advances, yet it does not appear that this scientific understanding had formally entered into the design work done for either city. Just a few decades after the rebuilding of Lisbon, professional engineering finally came into its own. In 1771 John Smeaton and some of his colleagues formed what became known as the Smeatonian Society of Civil Engineers. This is believed to be one of the first societies of professional engineers. The word civil was meant to distinguish them from engineers who emerged from military academies. In 1794, the École Polytechnique was established in Paris with the goal of training young men in scientific disciplines for civil service. Over the first few years of its existence a formal engineering curriculum for training civil engineers was created at the École Polytechnique and mathematical rebuilding became part of common practice in Europe (Wells 2010, p. 106).

\section{References}

Bennett, Jim, Michael Cooper, Michael Hunter and Lisa Jardine. 2003. London's Leonardo, The Life and Work of Robert Hooke. Oxford: Oxford University Press.

Carneiro, Ana, Ana Simones and Maria Paula Diogo, Enlightenment Science in Portugal: The Estrangeirados and Their Communication Networks. Social Studies of Science 30(4): 591-619.

Cóias e Silva, V, Paulo B. Lourenço, Luís F. Ramos and Carlos G. Mesquita. 2001. Accounting for the "Block Effect" in Structural Interventions in Lisbon's old "Pombaline" Downtown Buildings. In: Historical Constructions, eds. P.B. Laurenco, Po. Roca, 943-952. Guimaraes: Universidade do Minho.

Cooper, Michael. 2003. A More Beautiful City: Robert Hooke and the Rebuilding of London After the Great Fire. Stroud: Sutton Publishing. 
Dutu, A., J. Gomes Ferreira, L. Guerreiro, F. Branco and A. M. Goncalves. 2012. Timbered Masonry for Earthquake Resistance in Europe. Materiales de Construccion 62(308): 615-628.

Falter, Holger. 1998. The Influence of Mathematics on the Development of Structural Form. In: Nexus II Architecture and Mathematics, ed. Kim Williams, 51-64. Fucecchio: Edizioni dell'Erba.

Figueiredo, Fernando and João Fernandes, 2006, José Monteiro da Rocha: A Portuguese Astronomer and Mathematician. The Work on Comets. CIM Bulletin (21): 26-28.

Franca, José-Augusto. 1989. A reconstrução de Lisboa e a arquitectura pombalina. Amadora: Institutio de Cultura e Lingua Portuguesa.

Francis, A.D. 1960. John Methuen and the Anglo-Portuguese Treaties of 1703. The Historical Journal 3(2): 103-124.

Gerbino, Anthony and Stephen Johnston. 2009. Compass and Rule: Architecture as Mathematical Practice in England. London: Yale University Press.

Gregory, David. 1697. Davidis Gregorii M. D. Astronomiae Professoris Sauiliani and S. R. S. Catenaria, Ad Reverendum Virum D. Henricum Aldrich S. T. T. Decanum Aedis Christi Oxoniae. Philosophical Transactions of the Royal Society 19(1695-1697): 637-652.

Heyman, Jaques. 1998. Hooke's Cubico-Parabolical Conoid. Notes and Records of the Royal Society of London 52(1): 39-50.

Hooke, Robert. 1935. The Diary of Robert Hooke MA, MD, FRS, 1672-1680. Eds. Henry Robinson and Walter Adams. London: Taylor Francis.

Jardine, Lisa. 1999. Ingenious Pursuits. New York: Doubleday.

Jardine, Lisa. 2002. On a Grander Scale: The Outstanding Life of Sir Christopher Wren. New York: Harper Collins.

Kendrick, T. D. 1955. The Lisbon Earthquake. Philadelphia: J.B. Lippincott.

Leitao, Henrique. 2003. Jesuit Mathematical Practice in Portugal, 1540-1759. In: The New Science and Jesuit Science: Seventeenth Century Perspectives, ed. M. Feingold, 229-247. Dordrecht: Kluwer Academic Publishers.

Lodge, Richard. 1933. The English Factory at Lisbon: Some Chapters in Its History. Transactions of the Royal Historical Society. Fourth series. 16: 211-247.

Mascarenhas, Jorge Morarji Dias. 1996. A Study of the Design and Construction of Buildings in the Pombaline Quarter of Lisbon. Ph.D. thesis, University of Glamorgan.

Meli, Domenico Bertoloni. 2006. Thinking with Objects: The Transformation of Mechanics in the Seventeenth Century. Baltimore: Johns Hopkins University Press.

Mullin, John R. 1992. The Reconstruction of Lisbon Following the Earthquake of 1755: A Study in Despotic Planning. Architecture and Regional Planning Faculty Publication Series. Paper 45. http:// scholarworks.umass.edu/larp_faculty_pubs/45.

Pepys, Samuel. 1999. A Pepys Anthology, Passages from the Diary of Samuel Pepys, eds. Robert Latham and Linnet Latham. Berkeley: University of California Press.

Saraiva, Luis Manuel Ribero. 1993. On the First History of Portuguese Mathematics. Historia Mathematica 20: 415-427.

Smith, John. 1845. Memoirs of the Marquis of Pombal; With Extracts from His Writings, and from Despatches in the State-Paper Office, Never before Published by Marquis of Pombal. The North American Review 60(127): 478-488.

Wells, Matthew. 2010. Engineers: A History of Engineering and Structural Design. New York: Routledge.

Zack, Maria. 2008. Robert Hooke's Fire Monument: Architecture as a Scientific Instrument. In: Nexus VII Architecture and Mathematics, ed. Kim Williams, 117-126. Fucecchio: Edizionidell'Erba.

Maria Zack received her undergraduate degree and doctorate in mathematics from the University of California, San Diego. Her research interests include the history of mathematics, the intersection of mathematics and architecture, and the philosophy of higher education. She has worked as research staff of the Institute for Defense Analysis and is currently the Chair of the Department of Mathematical, Information and Computer Sciences at Point Loma Nazarene University in San Diego, California, USA. In her spare time she volunteers with the Medical Benevolence Foundation traveling internationally to help strengthen indigenous health care systems in developing nations. 